\title{
Graves' disease in a mediastinal mass presenting after total thyroidectomy for nontoxic multinodular goiter
}

$S \tilde{A} \bigcirc \mathrm{JOA} O$

Cunha $\mathrm{FM}^{1,2}$, Rodrigues $\mathrm{E}^{1,2}$, Oliveira $\mathrm{J}^{1,2}$, Vinhas $\mathrm{L}^{3}$, Carvalho $\mathrm{D}^{1,2}$

${ }^{1}$ Serviço de Endocrinologia, Diabetes e Metabolismo do Centro Hospitalar de São João EPE; ${ }^{2}$ Faculdade de Medicina da Universidade do Porto,

${ }^{3}$ Serviço de Cirurgia Geral do Centro Hospitalar de São João

\section{Introdution}

Thyrotoxicosis after total thyroidectomy (TT) is mostly iatrogenic. Rarely, an hyperfunctional thyroid remnant or ectopic tissue may be the cause.

We report a case of Graves's disease in a mediastinal thyroid mass presenting 7 years after TT for nontoxic goiter.

\section{Case Report}

\section{History}

A 67 years old caucasian woman was admitted to the emergency department with palpitations, and dizziness in the last two days. She had fatigue for minor efforts, weight loss $(11 \mathrm{Kg}$ in 3 years) without anorexia, and hand tremor. She had no other complaints.

History of breast cancer at the age of 37 and treated with right radical mastectomy and adjuvant chemotherapy.

Total thyroidectomy for nontoxic multinodular goiter with a dominant colloid nodule of $30 \mathrm{~mm}$ at the age of 60 ; the histological analysis confirmed multinodular adenomatous goiter with no signs of malignancy. She was medicated with levothyroxine $100 \mu \mathrm{g} /$ day since the surgery.

Smoker: 20 cigarettes a day for the last 50 years.

She did not take any other medications. Family history was irrelevant.

Physical examination

Weight: $45 \mathrm{Kg}$; height: $151 \mathrm{~cm}$; BMI 19,7 Kg/m²

BP: $122 / 76 \mathrm{mmHg}$; HR: 130/min; Temp $36,7^{\circ} \mathrm{C}$

Warm and dry skin. No exophthalmia, no lid retraction or palpebral oedema

Cervical examination: no palpable masses, and no adenomegaly.

The pulmonary sounds were normal and she had no cardiac murmur.

No peripheral oedema. Fine tremor at rest.

\section{Complementary Diagnostic Tests}

\begin{tabular}{|c|c|c|c|c|c|}
\hline Haemoglobin & $11,5 \mathrm{~g} / \mathrm{dL}$ & & AST & $22 \mathrm{U} / \mathrm{L}$ & $(10-31)$ \\
\hline Leukocytes & $9280 / \mu \mathrm{L}$ & & ALT & $14 \mathrm{U} / \mathrm{L}$ & $(10-31)$ \\
\hline Platelets & $219000 / \mu \mathrm{L}$ & & GGT & $13 \mathrm{U} / \mathrm{L}$ & $(7-32)$ \\
\hline Glycose & $84 \mathrm{mg} / \mathrm{dL}$ & & Alk Phosphatase & $84 \mathrm{U} / \mathrm{L}$ & $(30-120)$ \\
\hline Creatinine & $0,80 \mathrm{mg} / \mathrm{dL}$ & & Total Bilirubin & $0,42 \mathrm{mg} / \mathrm{dL}$ & $(<1,2)$ \\
\hline Urea & $35 \mathrm{mg} / \mathrm{dL}$ & & Direct Bilirubin & $0,08 \mathrm{mg} / \mathrm{dL}$ & $(<0,4)$ \\
\hline $\begin{array}{l}\mathrm{Na}^{+} \\
\mathrm{K}^{+}\end{array}$ & $\begin{array}{l}139 \mathrm{mEq} / \mathrm{L} \\
4,6 \mathrm{mEq} / \mathrm{L}\end{array}$ & & $\mathrm{BNP}$ & $442,2 \mathrm{pg} / \mathrm{mL}$ & $(<100)$ \\
\hline Free T4 & $3,22 \mathrm{ng} / \mathrm{dL}$ & $(0,70-1,48)$ & Troponin I & $0,010 \mathrm{ng} / \mathrm{mL}$ & $(<0,08)$ \\
\hline Free T3 & $8,46 \mathrm{pg} / \mathrm{mL}$ & $(1,71-3,71)$ & Myoglobin & $26,2 \mathrm{ng} / \mathrm{mL}$ & $(<146,9)$ \\
\hline TSH & $0,000 \mu \mathrm{U} / \mathrm{mL}$ & $(0,35-4,94)$ & CK-MB & $0,60 \mathrm{ng} / \mathrm{mL}$ & $(0,0-6,4)$ \\
\hline
\end{tabular}

Electrocardiogram: Sinus tachycardia $114 \mathrm{bpm}$, without others abnormalities

Chest Roentgenogram: Normal cardiothoracic index, no signs of pulmonary venous congestion. No tracheal deviation.

Admitted to the Endocrinology Department with the diagnosis of iatrogenic thyrotoxicosis.

\section{Evolution}

Levothyroxine was stoped. Started bisoprolol 5mg/day.

Haemodynamically stable. Persistence of the rest tremor.

\begin{tabular}{lll|} 
D10 after admission & & \\
\hline Free T4 & $3,11 \mathrm{ng} / \mathrm{dL}$ & $(0,70-1,48)$ \\
Free T3 & $9,31 \mathrm{pg} / \mathrm{mL}$ & $(1,71-3,71)$
\end{tabular}

Complementary Diagnostic Tests

\begin{tabular}{|c|c|c|c|}
\hline \multirow{3}{*}{ Thyroglobulin $294 \mathrm{ng} / \mathrm{mL} \quad(0-55)$} & & & \\
\hline & \multicolumn{3}{|c|}{ 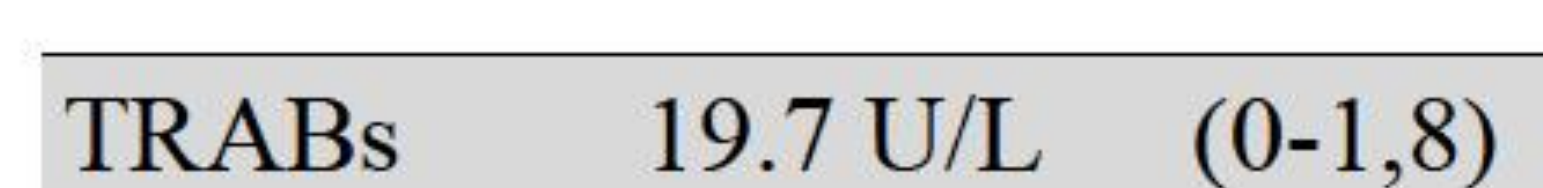 } \\
\hline & Anti-TPO & $0,6 \mathrm{U} / \mathrm{mL}$ & $(<5,61)$ \\
\hline
\end{tabular}

Cervical ultrassound: no thyroid remnant in the gland bed.
Thyroid scintigraphy with I-131 and SPECT:

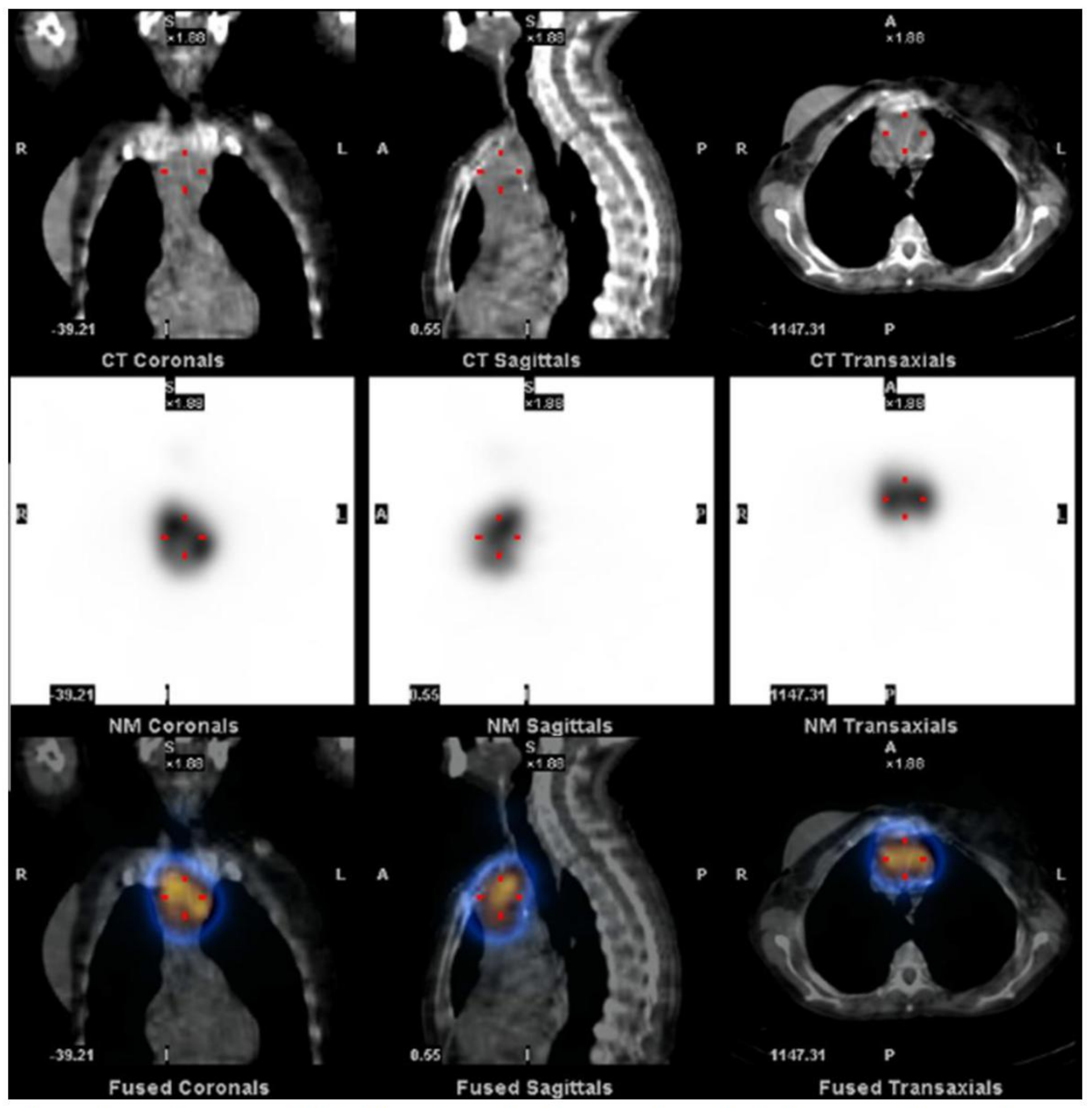

Intrathoracic mass $(60 \times 40 \mathrm{~mm})$ with increased radioiodine uptake, and no increased uptake in the thyroid bed

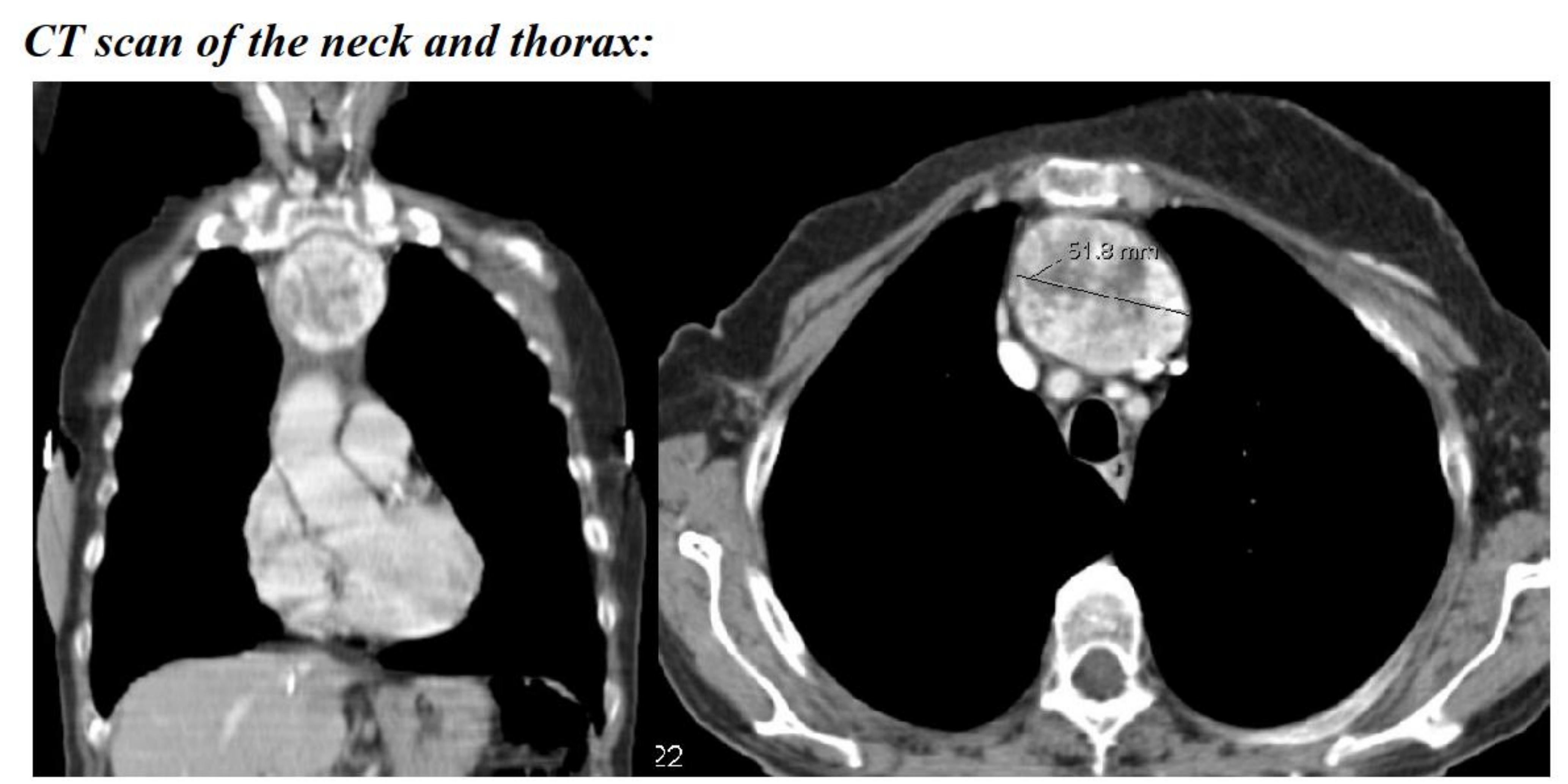

Heterogenous mass of $67 \times 46 \times 52 \mathrm{~mm}$ in the superior mediastin.

\section{Diagnosis}

Graves' disease in a mediastinal thyroid mass

\section{Treatment}

Methimazole $10 \mathrm{mg} /$ day, and bisoprolol $5 \mathrm{mg} /$ day

Three months later she was euthyroid and the mass was removed.

Histology: hyperfunctional tissue with thyroid follicles of variable shape and form with papillary hyperplasia and some adenomatous areas; no signs of malignancy.

\section{Discussion}

Although thyrotoxicosis after total thyroidectomy is mostly due to excessive supplementation, physicians should keep in mind the possibility of true hyperthyroidism.

The presence of thyroid tissue after TT in our patient may correspond to a remnant or, less likely, ectopic thyroid tissue that became hyperfunctional in the presence of TRAb's. 